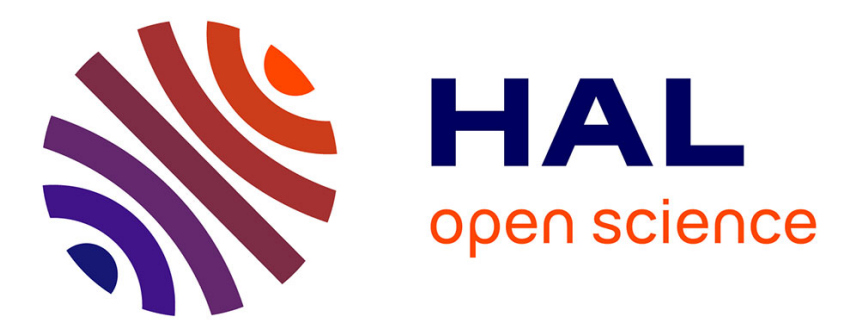

\title{
INTERTEMPORAL PREFERENCE PARAMETERS FOR SOME EUROPEAN MONETARY UNION COUNTRIES
}

\author{
Elena Marquez, Ana R. Martinez Cañete, Ines Perez-Soba Aguilar
}

\section{- To cite this version:}

Elena Marquez, Ana R. Martinez Cañete, Ines Perez-Soba Aguilar. INTERTEMPORAL PREFERENCE PARAMETERS FOR SOME EUROPEAN MONETARY UNION COUNTRIES. Applied Economics, 2007, 39 (08), pp.997-1011. 10.1080/00036840500462012 . hal-00581968

\section{HAL Id: hal-00581968 https://hal.science/hal-00581968}

Submitted on 1 Apr 2011

HAL is a multi-disciplinary open access archive for the deposit and dissemination of scientific research documents, whether they are published or not. The documents may come from teaching and research institutions in France or abroad, or from public or private research centers.
L'archive ouverte pluridisciplinaire HAL, est destinée au dépôt et à la diffusion de documents scientifiques de niveau recherche, publiés ou non, émanant des établissements d'enseignement et de recherche français ou étrangers, des laboratoires publics ou privés. 


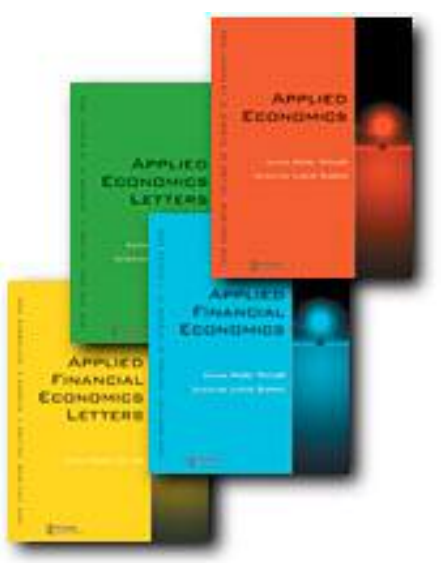

\section{INTERTEMPORAL PREFERENCE PARAMETERS FOR SOME EUROPEAN MONETARY UNION COUNTRIES}

\begin{tabular}{|c|c|}
\hline Journal: & Applied Economics \\
\hline Manuscript ID: & APE-05-0402 \\
\hline Journal Selection: & Applied Economics \\
\hline $\begin{array}{r}\text { Date Submitted by the } \\
\text { Author: }\end{array}$ & 22-Jul-2005 \\
\hline JEL Code: & $\begin{array}{l}\text { E44 - Financial Markets and the Macroeconomy < E4 - Money and } \\
\text { Interest Rates < E - Macroeconomics and Monetary Economics, G12 } \\
\text { - Asset Pricing < G1 - General Financial Markets < G - Financial } \\
\text { Economics }\end{array}$ \\
\hline Keywords: & $\begin{array}{l}\text { intratemporal non-separability of preferences, intratemporal } \\
\text { elasticity of substitution, intertemporal elasticity of substitution, } \\
\text { durable and nondurable consumption }\end{array}$ \\
\hline
\end{tabular}




\title{
INTERTEMPORAL PREFERENCE PARAMETERS FOR SOME EUROPEAN MONETARY UNION COUNTRIES
}

\author{
Running Tittle: Intertemporal Preference Parameters
}

\begin{abstract}
In the European Monetary Union, the estimation and analysis of preference parameters in its members is of special interest because possible differences could help us to understand why a common monetary policy could have different effects on the different economies involved. In this paper we have focused our attention on the elasticity of intertemporal substitution, one of the key preference parameters in intertemporal macroeconomic models.

Different studies have shown a possible underestimation of such elasticity for different countries. It is common practice to estimate the parameter using only nondurable goods and service consumption data, without referring to the service flows generated by durable consumption. This is only admissible if the intratemporal utility can be separated among the different consumption components. Our priority objective is therefore to test the assumption of intratemporal separability for a selection of European countries (Germany, Spain and France), and then to analyse the effect of durable consumption on the estimated values of the intertemporal elasticity of substitution of these countries, our ultimate goal. Knowledge of such elasticity will enable us to characterise how saving in these economies reacts to variations in the real interest rate.

Key words: intratemporal non-separability of preferences; intratemporal elasticity of substitution; intertemporal elasticity of substitution; durable and nondurable consumption.
\end{abstract}

JEL classification: E44, G12. 


\section{Introduction}

The fundamental goal of this paper is the estimation and analysis of the intertemporal preference parameters, that is the subjective discount factor and intertemporal elasticity of substitution, shown by investors-consumers in Germany, Spain and France in the long term.

These preference parameters have often been estimated within the context of the consumption-based capital asset pricing model, CCAPM, developed by Lucas (1978). In different cases, their empirical estimation has given rise to puzzling intertemporal elasticity of substitution estimates; specifically, the estimated values of this parameter can be considered abnormally low ${ }^{1}$, and are even negative in some cases, such as in the work of Hall (1988) and Hansen and Singleton (1996) for the North American economy. Focusing on the countries we have mentioned, we find puzzling estimates of the parameter in the work of, among others, Rubio (1995) and Rodríguez López (1997) for Spain, Lund and Engsted (1996) and Meyer (1999) for Germany, Girardin, Sarno and Taylor (2000) for France, and Cuthberston and Hyde (2003) for Germany and France.

The literature provides different explanations for the difficulties with which the consumption-based capital asset pricing model adjusts to empirical evidence. In the first place, some authors consider that the specification of preferences normally used since Hansen and Singleton (1982, 1983) is inappropriate, so the resolution of the abnormal values detected would require alternative agent preference specifications ${ }^{2}$. On the other hand, the omission of durable consumption in the estimation of preference parameters, a common practice which may not be appropriate insofar as preferences which are intratemporally inseparable could introduce a downwards bias into the 
estimates of intertemporal elasticity of substitution. This is the fundamental reason presented by Ogaki and Reinhart (1998a, 1998b) to explain abnormally low estimates of intertemporal elasticity of substitution, and the same line is followed by Dunn and Singleton (1986), Eichenbaum and Hansen (1990), López Salido (1993), Mamaysky (2001), Okubo (2002), Pakos (2004), Wirjanto (2004) and Yogo (2005) ${ }^{3}$.

Our research is therefore based on the hypothesis of the impact that durable consumption might have on the estimation of certain preference parameters in the context of the CCAPM model. We have to analyse the degree to which preferences are intratemporally separable, since only if this is confirmed can durable consumption be omitted from the analysis. We therefore estimate the intratemporal elasticity of substitution between nondurable and durable consumption followed by an estimation of the subjective discount factor and intertemporal elasticity of substitution with the consumption data identified as most appropriate by the intratemporal separability analysis.

These estimates are performed for three European countries, Germany, Spain and France, with a two-fold purpose: on the one hand, we aim to verify whether the results are robust; and on the other, since they are members of a monetary union and monetary policy is therefore common to them all, we aim to analyse the possible differences between the values of the preference parameters of the different economies involved; should such differences exist, they could help us to understand the diverse effects that such a common policy could have on saving in the different countries. Besides studying these three economies, and unlike the other empirical studies examined, we also introduce an analysis of current preferences between durable and nondurable consumption when they are not homothetic. The analysis becomes more 
robust from an econometric perspective because the model is tested using two different cointegration methods, Park (1992) and Johansen (1995).

The paper is organised as follows: firstly, in section 2 , we briefly describe the theoretical model and econometric methods used in the estimation. Section 3 contains the results of our estimation of the intratemporal elasticity of substitution between durable and nondurable consumption following the approach adopted by Ogaki and Reinhart (1998a) and Pakos (2004). In section 4, we go on to use the two-stage Generalised Method of Moments (GMM) to estimate the Euler Equation resulting from the intertemporal maximisation of investors, using consumption data considering the flow of services generated by durable consumption and thus obtaining intertemporal elasticity of substitution estimates for the countries considered. Finally, section 5 contains our conclusions. The Appendix provides details of the consumption series employed.

\section{The model and the testing methods}

\subsection{The model}

We follow the model adopted by Ogaki and Reinhart (1998a). Intertemporal preferences are expressed as

$$
U=E_{0}\left[\sum_{t=0}^{\infty} \beta^{t}\left(\frac{\sigma}{\sigma-1}\right)\left[u_{t}^{1-\frac{1}{\sigma}}-1\right]\right],
$$

where $\sigma>0$ is the intertemporal elasticity of substitution and $\beta>0$ is the subjective discount factor. Intratemporal utility is given by a function with constant elasticity of substitution (CES function):

$$
u_{t}=\left[a C_{t}^{1-\frac{1}{\varepsilon}}+S_{t}^{1-\frac{1}{\varepsilon}}\right]^{\frac{1}{1-\frac{1}{\varepsilon}}}, \varepsilon>0, a>0
$$

$C_{t}$ is the consumption of nondurable goods and services, $S_{t}$ is the flow of 
services generated by durable good consumption, $\varepsilon$ is the intratemporal elasticity of substitution between the consumption of nondurable and durable goods and $a$ is a positive constant showing the importance of nondurable consumption for the current utility of agents ${ }^{4}$. With regards to $S_{t}$, durable consumption generates services beyond the period in which the expenditure occurs, as represented in the expression

$$
S_{t}=D_{t}+\delta D_{t-1}+\delta^{2} D_{t-2}+\ldots, 0<\delta<1,
$$

where $(1-\delta)$ is the rate of depreciation of durable goods and $D_{t}$ is the expenditure on durable consumption in period $t$.

The maximisation of the intertemporal utility of the agents would be represented by the following Euler equation,

$$
E_{t}\left[\beta \frac{U M a_{1, t+1}}{U M a_{1, t}} R_{t+1}^{i}\right]=1, \forall i
$$

where $R_{t+1}^{i}$ is the gross rate of return of asset $i$ during period $t$ and $U M a_{1, t}$ is the marginal utility of the consumption of nondurable goods and services in period $t$.

Since this is a model with two goods, it is possible to exploit the first-order condition that shows that, for each period $t$, the relative price of the assets, $P_{t}$, must be equal to the marginal rate of substitution between them, as follows:

$$
P_{t}=\frac{E_{t}\left[\sum_{\tau=0}^{\infty} \beta^{\tau} \delta^{\tau} U M a_{2, t+\tau}\right]}{U M a_{1, t}}
$$

where $U M a_{2, \tau}$ is the marginal utility of the flow of services generated by durable consumption.

Multiplying the two members of the previous expression by $\left(\frac{C_{t}}{D_{t}}\right)^{-\frac{1}{\varepsilon}}$ and operating, we obtain: 


$$
P_{t}\left[\frac{C_{t}}{D_{t}}\right]^{-\frac{1}{\varepsilon}}=E_{t}\left[\left(\frac{1}{a}\right) \sum_{\tau=0}^{\infty} \beta^{\tau} \delta^{\tau}\left(\frac{S_{t+\tau}}{D_{t}}\right)^{-\frac{1}{\varepsilon}}\left(\frac{C_{t}}{C_{t+\tau}}\right)^{-\frac{1}{\varepsilon}} \frac{U M a_{1, t+\tau}}{U M a_{1, t}}\right]
$$

This expression is the basis for estimating the intratemporal elasticity of substitution between the two types of asset. When $\varepsilon=\sigma$, we could converge to the separable model, because in this case the intertemporal marginal rate of substitution would only depend on the consumption of nondurable goods ${ }^{5}$.

In the above Ogaki and Reinhart model, the current preferences are homothetic. Pakos (2004) contemplates the possibility of the two types of asset being considered actually having a low degree of substitutability, and being largely complementary, since it seems sensible to assume that joint consumption of durable and nondurable assets would increase agent utility. Pakos also analyses the possibility of the income effect playing an important role in the determination of relative consumption. The current utility function proposed by Pakos is as follows:

$$
u\left(C_{t}, S_{t}\right)=\left\{\left(a C_{t}\right)^{1-\frac{1}{\varepsilon}}+S_{t}^{1-\frac{\eta}{\varepsilon}}\right\}^{\frac{\varepsilon}{\varepsilon-1}}, \eta>0
$$

where $\eta$ is the quotient of the income elasticities of nondurable, $\eta_{1}$, and durable consumer goods, $\eta_{2}$. In this case, the first-order condition equivalent to equation [6] would be:

$$
\text { [8] } P_{t}\left(\frac{C_{t}}{D_{t}^{\eta}}\right)^{-\frac{1}{\varepsilon}}=E_{t}\left[\sum_{\tau=0}^{\infty} \beta^{\tau} \delta^{\tau}\left(\frac{1}{a^{1-\frac{1}{\varepsilon}}}\right)\left(\frac{S_{\tau+1}^{\eta}}{C_{t+1}}\right)^{-\frac{1}{\varepsilon}}\left(\frac{C_{t}}{D_{t}^{\eta}}\right)^{-\frac{1}{\varepsilon}} \frac{U M a_{1, \tau+1}}{U M a_{1, \tau}} \frac{\varepsilon-\eta}{\varepsilon-1}\right]
$$

Once again, under certain assumptions, we could estimate parameters $\varepsilon$ and $\eta$ with a cointegration approach.

\subsection{Econometric method}

Ogaki and Reinhart (1998a) show that, under certain assumptions, the righthand side of expression [6] is stationary ${ }^{6}$, so if we take logarithms on the lefthand size of the expression, we could obtain that variables $\left(p_{t}, c_{t}-d_{t}\right)$ are 
cointegrated, with $(1,-1 / \varepsilon)$ being the cointegration vector. To estimate this cointegration vector, we consider the following expression:

$$
p_{t}=\mu+\frac{1}{\varepsilon}\left(c_{t}-d_{t}\right)+v_{t}
$$

where $v_{t}$ is a zero mean stationary process and $\mu$ is a constant. In the case of non-homothetic preferences, equation [8] would lead us to the following cointegration regression

$$
c_{t}=b+\varepsilon p_{t}+\eta d_{t}+v_{t}
$$

where, again, $b$ is a constant and $v_{t}$ is a zero mean stationary process. It is possible to show that, although the ordinary least squares estimator is superconsistent, it is not asymptotically efficient, so we will estimate the parameters involved using a cointegration approach.

Specifically, following Ogaki and Reinhart (1998a), we have estimated the intratemporal elasticity of substitution using the canonical cointegration method proposed by Park (1992) $)^{7}$ We will also use the $H(p, q)$ test proposed by Park (1990) for the cointegration analysis. This test enables us to test both the determinist $H(0,1)$ and stochastic $H(1, q)^{8}$ cointegration hypothesis.

We have also estimated the parameters according to the Johansen (1995) method. The essential idea is to analyse the degree to which the results obtain change according to the method of estimation employed and, when applicable, confirm these results ${ }^{9}$. The Johansen method is based on considering a VAR of order $p$ which can be expressed in the form of an error correction model as

$$
\Delta Y_{t}=\mu+\Gamma_{1} \Delta Y_{t-1}+\ldots+\Gamma_{p-1} \Delta Y_{t-p+1}+\Pi Y_{t-1}+e_{t}
$$

where $Y_{t}$ is a vector of $m$ variables $I(1)$.

If the range of matrix $\Pi$ is less than $m$, this matrix can be broken down as

$$
\Pi=\alpha \beta^{\prime}
$$


where $\beta$ contains the cointegration ratio parameters and $\alpha$ contains the adjustment parameters. The range of $\Pi$ indicates the number of cointegration ratios and can be tested by the maximum likelihood estimation of the trace test ${ }^{10}$.

The asymptotic distributions of the trace test change depending on the hypotheses constructed on the deterministic terms in the error correction model. In this respect, Nielsen and Rahbek (2000) showed that, if the data contains linear trends (which would lead to $E\left[\Delta Y_{t}\right] \neq 0$ ), testing the cointegration rank starting with a specification including a trend restricted to the cointegration vector induces "similarity" in the testing procedure, meaning that the critical trace test values do not depend on the values of the parameters. It is subsequently possible to test whether this trend is significant or not and, if not, estimate the model using a specification comprising a constant not restricted to the cointegration vector. However, if $E\left[\Delta Y_{t}\right]=0$ (there is no trend in the data), according to this similarity argument, the cointegration rank should be tested considering a constant restricted to the long-term ratio ${ }^{11}$. In this paper, the specification of the deterministic terms has been based on this procedure.

\section{Intratemporal elasticity of substitution in}

\section{Germany, Spain and France}

\subsection{Unit root test}

The first step before applying the cointegration approach consists of analysing whether the series involves are stationary or not. Estimation of intertemporal elasticity of substitution by the GMM method also requires the series employed to be stationary. For these two reasons, we use the usual unit root tests in order to analyse whether the series employed meet the required 
conditions or not. We specifically apply the ADF test and the Phillips-Perron unit root test to the following series: relative consumption, relative price, real interest rate and real rate of return.

The relative consumption data are annual for the three countries and cover 1970-2003 for Germany, 1964-2001 for Spain and 1960-2001 for France. To calculate the relative price of durable and nondurable consumer goods, we first calculate the deflator for each type of good and then find the ratio between them. As for the rate of return of the risk-free asset, for Germany it corresponds to the annual 3-month interest rate on the interbank market published by the IMF. For Spain, we take the mean interest rate of the different one-year treasury bond issues (1987-2001) and the internal stock market return on electric bonds ${ }^{12}$ (1964-1986); the data comes from the Bank of Spain. For France, we use the rate of interest on government bonds (one year or more) provided by the IMF. Finally, as a proxy variable of the rate of return on risk assets, we have taken the market yield for each of the countries considered. For Germany, we have considered the annual mean of the Total DAX30 Index, for Spain, the Total General Madrid Stock Market Index (IGTBM) and for France, the Paris stock exchange CAC40 index. In all these cases, we use the variation in the nondurable consumer good expenditure deflator to calculate both the real interest rate and the real rate of return.

As we can see on Table 1, the results of the augmented Dickey-Fuller (ADF) and Phillips-Perron (PP) unit root tests for the relative price logarithm $p_{t}$, and the logarithmic difference of the two types of consumption $\left(c_{t}-d_{t}\right)$ show that consumption and relative price are variable $I(1)$ both for Spain and for Germany (for a 5\% level of significance). The procedure proposed by Holden and Perman (1994) to determine the true data generating process enables us to confirm the non-stationarity of relative consumption for these 
two countries. The same applies to France. Therefore, we can conclude that both consumption and relative price are $I(1)$ series in the countries analysed. Note that this is a condition required in order to apply the cointegration approach.

With regards to the real interest rates ${ }^{13}$, the tests employed indicate that this variable is $I(1)$ for France. In Germany and Spain, however, it can be considered $I(0)$, because the existence of unit root cannot only be rejected in the model including neither a constant nor a trend, which can be dismissed as the true data generating process if we use the Holden and Perman procedure mentioned earlier.

As for each country's representative rate of return on risk assets, we cannot dismiss the existence of unit root in model (3), which again fails to correspond to the true data generating process.

In sum, the rates of return on risk assets are stationary in the three countries considered, whereas this only applies to the real interest rate in Germany and Spain.

\subsection{Results of the estimation according to the Park and Johansen}

\section{cointegration methods}

The cointegration tests performed with the canonical cointegration method and the Johansen maximum likelihood method, and the results of the intratemporal elasticity of substitution estimations, are shown on Tables 2 and 3 , respectively.

\subsubsection{Germany}

As Table 2 shows, Park's $H(p, q)$ test does not enable us to dismiss the existence of both determinist and stochastic cointegration between the variables. The estimated value of $\mu$ is significantly different from zero but, 
although the sign is correct, the intratemporal elasticity of substitution is not significant.

According to the Johansen method, there is a cointegration ratio between relative consumption and prices ${ }^{14}$. The model has been specified with a constant restricted to the cointegration vector because, in the German case, $E\left[\Delta\left(c_{t}-d_{t}\right)\right]=-0.002$ and $E\left[\Delta p_{t}\right]=-0.005$. Is can be seen that the constant is significant (on the $10 \%$ limit) but it cannot be dismissed that price $p_{t}$ is not part of the long-term ratio; in other words, that $\varepsilon$ is not significantly different from zero ${ }^{15}$.

The fact that the estimated value of the intratemporal elasticity of substitution is not significant (Table 3), has led us to consider the specification of the utility function proposed by Pakos (2004), which analyses the possibility of the income effect playing an important role in the determination of relative consumption $^{16}$.

In this case, Park's $H(p, q)$ test rejects the null hypothesis of determinist cointegration, but not stochastic cointegration. The results show that, in this case, $\varepsilon$ it is significantly different from zero, like parameter $\eta$. The fact that this is less than a unit, indicates that $\eta_{1}<\eta_{2}$; in other words, that the income elasticity of nondurable consumer goods is smaller than that of durable goods.

Furthermore, as we have mentioned, $E\left[\Delta p_{t}\right]=-0.005$, the nondurable and durable consumption series point to a greater data trend possibility because $E\left[\Delta c_{t}\right]=0.026$ and $E\left[\Delta d_{t}\right]=0.028$, respectively. Therefore, as a pragmatic solution, we determine the cointegration rank according to the Johansen method, considering a constant restricted to the cointegration vector (model 1) and a trend likewise restricted (model 2), which also enables us to assess 
whether the results are very sensitive to the specification of the deterministic terms.

In model (1), the cointegration rank is $r=1$. Parameters $\varepsilon$ and $\eta$ are significant and they are also positive, as expected. The first of them is somewhat greater than results from canonical cointegration, whereas the second is very similar. With regards to model (2), we have also considered $r=1$. The trend is not significant so, according to the similarity argument mentioned earlier, once the rank was determined we have estimated the parameters, accepting that the data trend is cancelled in the cointegration vector and therefore considering a constant not restricted to the latter. Both the estimated parameters are positive and significant and closer to those obtained with canonical cointegration.

\subsubsection{Spain}

The Park (1990) test shows that the null hypothesis of both stochastic and determinist cointegration cannot be rejected for a $1 \%$ level of significance in any of the cases considered, although determinist cointegration is rejected for a $5 \%$ level of significance (Table 2). The estimated values of both $\mu$ and $\varepsilon$ are significantly different from zero. On the other hand, the results do not enable us to reject the null hypothesis $\varepsilon=1$, so we cannot dismiss the Cobb-Douglas utility function as valid for the Spanish case.

As for the Johansen method, a study of the series does not point to the existence of a data trend and we also obtain $E\left[\Delta\left(c_{t}-d_{t}\right)\right]=-0.014$ and $E\left[\Delta p_{t}\right]=-$ 0.007. The model has therefore been specified including a constant restricted to the cointegration vector. The cointegration rank is 1 and both the constant and the intratemporal elasticity of substitution are positive and significant, with the latter being slightly lower than is obtained with the Park method and very close to unit value. 
With a view to comparing the results with the German case, we have also estimated the utility function proposed by Pakos $(2004)^{17}$. This model is rejected for Spain by the Park test in nearly all the cases considered. The sign of parameter $\varepsilon$ is also incorrect, although it is not significant. With the data available, therefore, this model does not appropriately reflect the performance of relative consumption in Spain.

Neither are non-homothetic preferences supported by the results obtained with the Johansen method, since the estimated price coefficient is negative when considering both a constant and a trend restricted to the cointegration vector (the fact that $E\left[\Delta c_{t}\right]=0.031$ and $E\left[\Delta d_{t}\right]=0.045$ appears to indicate the possible presence of a trend in the series). The most appropriate cointegration rank is $r=1$ in model (1) and $r=2$ in model $(2)^{18}$. In the former, the price coefficient is significant, although this is not the case in the latter ${ }^{19}$.

\subsubsection{France}

The Park test does not enable us to reject the null hypothesis of both determinist and stochastic cointegration. The results of the estimation of intratemporal elasticity of substitution again indicate that both $\mu$ and $\varepsilon$ are significantly different from zero and that the intratemporal elasticity of substitution also has the correct sign. On the other hand, as in the Spanish case, it is not possible to reject the null hypothesis $\varepsilon=1$, so the Cobb-Douglas utility function cannot be dismissed as valid for France.

According to the Johansen method, observation of the series indicates that we can rule out the existence of a determinist trend, especially in relative consumption. The mean of the series in differences is also close to zero (specifically, $E\left[\Delta\left(c_{t}-d_{t}\right)\right]=-0.012$ and $\left.E\left[\Delta p_{t}\right]=-0.012\right)$. We therefore estimate the homothetic preference model considering a constant restricted to the cointegration vector. The information used to determine the cointegration rank 
suggests that it is 1 . The constant and price parameter are positive and significant, the latter to a $10 \%$ level $^{20}$.

Again, in order to compare these results with those obtained for Germany, we have also estimated the non-homothetic preference model, even though the proposal of Ogaki and Reinhart (1998) cannot be rejected. The model is rejected when we consider the Park test for a value of $q \geq 3$. Moreover, although the estimated value of $\varepsilon$ is significantly different from zero, the sign is incorrect. In the French case, as for Spain, the Ogaki and Reinhart (1998a) model appears to be the most appropriate.

Neither does the Johansen method support the model based on nonhomothetic preferences. The evolution of the consumption series (of both durable and nondurable assets) does not enable us to clearly exclude the presence of a data trend (indeed, $E\left[\Delta c_{t}\right]=0.029$ and $E\left[\Delta d_{t}\right]=0.041$ ), which has led us to estimate the model both disregarding the trend in the series (model 1) and considering the possibility of it existing (model 2). According to model (1), the most appropriate cointegration rank is $r=2$. The results are not too satisfactory because we have obtained that one of the cointegration rations could come from the fact that durable consumption is stationary and the other does not appropriately link the model's variables, since both the price and durable consumption parameters are unexpectedly negative. As for model (2), the cointegration rank is $\mathrm{r}=1$ and we obtain that the trend restricted to the cointegration vector is not significant. We therefore estimate the model considering an unrestricted trend, which does not provide the results expected because it cannot be rejected that $\varepsilon$ is both significant and negative.

\section{Estimation of intertemporal elasticity of}

\section{substitution}


To estimate the intertemporal elasticity of substitution, we will employ the Generalised Moments Model in two stages proposed by Ogaki and Reinhart (1998a) as a deviation from the Generalised Method of Moments (Hansen, 1982). In our model, and with the simplifying assumption that $a=1$, the Euler Equation [7] takes on the following form in the case of homothetic preferences

$$
1=E_{t}\left[\beta\left(\frac{C_{t+1}}{C_{t}}\right)^{-\frac{1}{\varepsilon}}\left(\frac{\left[C_{t+1}^{1-\frac{1}{\varepsilon}}+S_{t+1}^{1-\frac{1}{\varepsilon}}\right]}{\left[C_{t}^{1-\frac{1}{\varepsilon}}+S_{t}^{1-\frac{1}{\varepsilon}}\right]}\right)^{\frac{(\sigma-\varepsilon)}{\sigma(\varepsilon-1)}} R_{t+1}^{i}\right], \forall i
$$

and

$$
1=E_{t}\left[\beta\left(\frac{C_{t+1}}{C_{t}}\right)^{-\frac{1}{\varepsilon}}\left(\frac{C_{t+1}^{1-\frac{1}{\varepsilon}}+S_{t+1}^{1-\frac{\eta}{\varepsilon}}}{C_{t}^{1-\frac{1}{\varepsilon}}+S_{t}^{1-\frac{\eta}{\varepsilon}}}\right)^{\frac{\sigma-\varepsilon}{\sigma(\varepsilon-1)}} R_{t+1}^{i}\right], \forall i
$$

for non-homothetic preferences. The idea in Ogaki and Reinhart (1998a) is to introduce the estimated values of the parameters in the previous stage in equations [13] and [14] to proceed to estimate $\sigma$. This method does not affect the asymptotic distribution of the estimators obtained by the Generalised Method of Moments ${ }^{21}$.

The only requirement of estimation by GMM to verify all the desirable properties of the estimators are for the variables employed to be stationary ${ }^{22}$. On the other hand, estimation by the Generalised Method of Moments leads us to the need to consider the choice of instruments. From a theoretical perspective, the only requirement a variable has to meet to be an instrument is to be known by the agents at the time when they make their decisions. We have therefore completed the estimation considering two different groups of instruments, in order to analyse whether the results are sensitive to them. In order to mitigate the problem of temporal data aggregation on the estimations, following Hall (1988), Hansen and Singleton (1996) and Amano and Wirjanto 
(1997), among others, we have lagged the variables used as instruments two periods. The instruments considered are:

- $\quad I 1$ : it includes a constant, the total consumption growth rate lagged two periods and the real interest rate lagged two periods ${ }^{23}$.

- $\quad I 2:$ it includes a constant, the total consumption growth rate and the gross real rate of return of the stock exchange index considered in each case, both lagged two periods.

The estimations have been made jointly employing the real interest rate and the respective rate of return of the stock index of each country, except for France because, as we saw in section 3, the interest rate is not stationary, so it does not meet the condition required for the GMM estimator to show all the desirable properties. In the French case, therefore, we have estimated the model only considering the real rate of return of the CAC40 index. The results are shown on Table 4.

In all cases, the estimated values of both intertemporal elasticity of substitution and the subjective discount factor have the correct sign and are significantly different from zero. On the other hand, the model is not rejected in any case using the Hansen test. Except for France, the estimations appear to be sensitive to the instruments used, since they significantly differentiate between them.

If we compare the estimates of intertemporal elasticity of substitution with those obtained in previous papers for the countries considered, we see that in our case they are clearly higher. With regards to Germany, for instance, Meyer (1999), applying the Hansen and Jagannathan bounds technique to the basic CCAPM model ${ }^{24}$, obtains that the intertemporal elasticity of substitution values required for the model to adjust to the empirical evidence ranges, according to the consumption data employed, from 0.0006 to 0.0007 , much lower than the 
values obtained here. Using the same technique, Cuthberston and Hyde (2003) also obtain intertemporal elasticity of substitution values lower than those shown on Table 4, although they are higher than those obtained by Meyer ${ }^{25}$. On the other hand, Lund and Engstend (1996), using the GMM method, also obtain very low intertemporal elasticity of substitution values, which are in many cases not significantly different from zero. For Spain, Rubio (1995), using the basic model, obtains aversion to risk parameter values of over 60 , which implies intertemporal elasticity of substitution values of less than 0.016 . The results obtained by Rodríguez López (1997) again show intertemporal elasticity of substitution values not significantly different to zero in some cases; the results are especially puzzling when the basic model is considered. Finally, for France, Girardin et. al. (2000) present estimations of this parameter which are close to zero and Cuthberston and Hyde (2003) estimate that the relative risk aversion parameter values required for the model to satisfy Hansen and Jagannathan bounds, must be over 14, implying an intertemporal elasticity of substitution value of less than 0.07 .

If we compare the results with those obtained using the same model for other countries, we see that the estimations of $\sigma$ for the Spanish and French cases are higher than those obtained by Wirjanto (2004) for Canada, Ogaki and Reinhart (1998a, 1998b) for the United States, and Okubo (2002) for Japan. In the German case, the results with group of instruments $I 2$ come quite close to those obtained by Wirjanto (2004) for Canada. It is important to emphasise that in these papers, the value of the subjective discount factor is taken as given in the estimation ${ }^{26}$. Since the subjective discount factor and intertemporal elasticity of substitution are negatively related, and since the estimated values of $\beta$ in our case are lower than those established by Ogaki and Reinhart, it is not surprising to find that the estimated intertemporal elasticity of substitution 
is greater. On the other hand, it is important to mention that the estimated values of this parameter for Spain are consistent with the microeconometric estimations of the same parameter obtained by López Salido $(1993)^{27}$.

Furthermore, in the German case, we can see that, although the subjective discount factor estimated with group of instruments $I 2$ is close to that established by Ogaki and Reinhart, the estimated value of $\sigma$ is considerably higher. However, we must remember that while we consider non-homothetic preferences for Germany, Ogaki and Reinhart use homotheticity in their estimations.

If we compare the results obtained for the three countries analysed, we see that the estimated intertemporal elasticity of substitution is considerably lower in Germany than in Spain and France; this would mean that saving in Spain and France is more sensitive to real interest rate variations than in Germany. Nevertheless, this result must be taken with caution, because the intertemporal model being considered for Germany is not the same as the model contemplated for the other two countries. Furthermore, we also have to consider that the sample periods considered, although close, are different, and this could also be affecting the estimates.

Since we now have an estimation of both $\varepsilon$ and $\sigma$, we can test the intertemporal separability of the preferences; it is sufficient to test the null hypothesis $\sigma=\varepsilon$. In the German case, separability of preferences is rejected when we consider the estimates of $\sigma$ obtained with group of instruments $I 1$, but not with group of instruments I2. In the cases of Spain and France, however, the intratemporal separability of preferences is rejected in all the cases considered. The results, then, appear to indicate the non-intratemporal separability of preferences among the different consumption components for 
the three countries considered. This result is confirmed on Table 5, where we have estimated the separable model for Germany, France and Spain with group of instruments $I 1$; in order to analyse the effect of omitting one of the components of consumption expenditure on the estimated intertemporal elasticity of substitution value, we have taken the estimated value of the subjective discount factor in the non-separable model as given. The results obtained confirm the initial hypothesis, since the estimated intertemporal elasticity of substitution values are significantly lower than those obtained in the non-separable model, and are even negative for France; furthermore, in the Spanish case, the model is rejected by the Hansen test.

\section{Conclusions}

Intertemporal elasticity of substitution has been estimated in intertemporal models considering a single consumer good, specifically the consumption of nondurable goods, giving rise to values which are too low. The separable nature of the intratemporal utility function, which translates in practical terms into non-consideration of durable consumption expenditure, can bias preference parameter estimations. In this paper, we have estimated the intratemporal elasticity of substitution between durable and nondurable consumption for Germany, Spain and France, using the approach proposed by Ogaki and Reinhart (1998a, 1998b) in order to analyse whether the current utility is separable into the different consumption components. The estimation was performed considering annual consumption data and calculating the flow of services provided by durable consumption assuming that such goods generate services for a finite time and that the depreciation rate of durable consumption is greater the further away we are from the time of acquisition. 
We have also considered the utility function proposed by Pakos (2004), which considers non-homothetic intertemporal preferences.

With these premises, and using a cointegration approach, the results of this estimation for Germany, Spain and France show how intratemporal elasticity of substitution is significantly different from zero, although for Germany we have considered non-homothetic preferences, whereas for Spain and France we have estimated the elasticity value with homothetic preferences. Based on this result, we have considered it appropriate to introduce durable asset consumption in the intertemporal elasticity of substitution estimation.

The estimated intertemporal elasticity of substitution values for the three countries are all of the correct sign and significantly different from zero when the non-separable model is considered; the same occurs with the subjective discount factor which is also always less than 1. If we compare the estimations obtained in each of the countries analysed, we see that the estimated intertemporal elasticity of substitution values for Spain and France and higher than for Germany, showing that the reaction of consumers-investor to changes in the real interest rate is different in the countries considered. The results indicate that it is Spanish saving which reacts more strongly to shocks in the real interest rate and Germany saving which is less sensitive, although elasticity of substitution is positive in all cases, and over 1. Nevertheless, it is important to note that this result should be taken with caution because the current utility function used in the intertemporal elasticity of substitution estimation is different for Germany than for Spain and France. Not in vain, if we consider the intertemporal elasticity of substitution estimations for Spain and France with group of instruments $I 2$, we can see how the estimated values are quite close, which is not the case for Germany. Finally, the separable model can be clearly rejected for Spain and France, although not so clearly for Germany, 
since we cannot reject the null hypothesis of equality between intratemporal and intertemporal elasticities of substitution when group of instruments $I 2$ is used to estimate the latter. However, the estimation of the separable model has enabled us to see how the omission of a consumption expenditure component produces a downwards bias in the intertemporal elasticity of substitution estimations and, in this respect, the non-consideration of durable consumption could help to explain the puzzling estimates of this parameter obtained in previous works.

In sum, the results presented indicate a need to consider specifications of the current utility function which include durable good consumption as a utility-generating argument. We believe that this could help to improve the empirical results of macroeconomic models aimed at estimating intertemporal preference parameters and thus mitigate the different empirical puzzles detected when they are tested. On the other hand, there are significant differences in the parameters estimated for the three countries considered, which must be taken into account when analysing the impact that common EMU monetary policy could have on the different member countries. The scope of this paper would clearly be increased by applying the analysis to more member States and explicitly including both money and the monetary policy transmission mechanism in the model.

\section{Appendix: consumption data}

Unlike most other studies estimating preference parameters within the framework of the CCAPM model, our project requires distinguishing between expenditure on nondurable assets and services and expenditure on durable goods. To obtain the relevant information, we have referred to the National 
Accounts of the different countries concerned, specifically to the classification of consumption expenditure by function. The sample period covered in each case depends on the availability of data for the countries included in the analysis. The sources of information used and the sample period contemplated for the three countries are as follows:

- Germany: the data covers the $1970-2003$ period. It is annual data taken from the Statistisches Bundesamt Deutschland. Data at constant prices is based on the year 1995.

- Spain: the data covers the 1964-2001 period. For 1964-1994, we have taken the series from Uriel et. al. (2000), whereas for 19952001, the data comes from the National Accounts, based on 1995, published by the INE.

- France: the data covers the 1960-2001 period and comes from the Institut National de la Statisque et des Études Économiques, INSEE (2002). In this case, the base year is 1995 .

Having homogenised the consumption expenditure series for the different countries, we distinguished between expenditure on nondurable goods and services and durable goods. For this purpose, nondurable consumer goods and services include the following concepts:

1. Food products, beverages and tobacco.

2. Clothing and footwear.

3. House rental, heating and lighting.

4. Household entertainment goods and services.

5. Medical and healthcare services.

6. Maintenance and preservation of personal means of transport.

7. Use of public transport. 

8. Communications.
9. Entertainment, leisure and cultural services.
10. Other goods and services.

On the other hand, durable consumer goods include the following concepts:

1. Furniture, accessories and household appliances.

2. Purchase of vehicles.

3. Leisure, sport and cultural articles.

4. Books, newspapers and magazines.

5. Teaching.

To calculate the service flows generated by durable consumption, we have calculated the following expression

$$
S_{t}=\sum_{k=0}^{10} \delta_{t-k} D_{t-k}, \delta_{t}=1 .
$$

We have introduced two differences in relation to the work of Ogaki and Reinhart (1998a, 1998b):

1. In the first place, we have considered that durable consumption generates services during a finite number of periods. We specifically assume that durable consumption generates services for 11 years. This number was selected considering the mean lifespan of the most typical of durable consumption assets: cars. We referred to the Registered car, jeep and motorycle depreciation tables published by the Ministry of Public Finance for Spain $^{28}$

2. Secondly, we assume that the rate of depreciation of durable consumer goods, $\delta_{t-k}$, increases the further we get from the period in which they were purchased. In other words, we assume a variable rate of depreciation $^{29}$. 


\section{References}

Amano, Robert A. and T.S. Wirjanto (1997), "Intratemporal Substitution and Government Spending", Review of Economics and Statistics 79, $\mathrm{n}^{\circ}$ 4, pp. 605-9.

Bank of Spain (several years), Boletin Estadístico.

Campbell, John Y. (2003), "Consumption-Based Asset Pricing" in G. Constantinides, M. Harris and R. Stulz (Eds.)(2003), Handbook of the Economics of Finance, vol. 1B, chap. 13. (Amsterdam: Elsevier).

Campbell, John Y. and J.H. Cochrane (2000), "Explaining the Poor Performance of the Consumption-Based Asset Pricing Models", Journal of Finance 55, no 6, pp. 2863-78.

Cuthberston, Keith and S. Hyde (2003), "Resurrecting the C-CAPM: Evidence from France and Germany", mimeo, Manchester School of Accounting and Finance.

Dunn, K.B. and K.J. Singleton (1986), "Modelling the Term Structure of Interest Rates under Non-Separable Utility and Durability of Goods", Journal of Financial Economics 17, pp. 27-55.

Eichenbaum, Martin and L.P. Hansen (1990), "Estimating Models with Intertemporal Substitution Using Aggregate Time Series Data", Journal of Business and Economic Statistics 8, $\mathrm{n}^{\circ}$ 1, pp. 53-69.

Epstein, Larry G. and S.E. Zin (1991), "Substitution, Risk Aversion, and the Temporal Behaviour of Consumption and Asset Returns: An Empirical Analysis", Journal of Political Economy 99, nº 2, pp. 263-86.

Esteve, Vicente and C.R. Tamarit (1994), "Determinantes de los tipos de interés reales a largo plazo en España”, Revista de Economía Aplicada 2, n 5, pp. 27-50.

Girardin, Eric, L. Sarno and M.P. Taylor (2000), "Private Consumption Behaviour, Liquidity Constraints and Financial Deregulation in France: a Nonlinear Analysis", Empirical Economics 25, pp. 351-68.

Gonzalo, Jesús (1994), "Comparisons of Five Alternative Methods of Estimating Long-Run Equilibrium Relations", Journal of Econometrics 60, pp. 203-34.

Hall, Robert E. (1988), "Intertemporal Substitution in Consumption", Journal of Political Economy 96, no 2, pp. 339-57.

Hansen, Lars P. (1982), "Large Sample Properties of the Generalized Method of Moments", Econometrica 50, pp. 1029-54. 
Hansen, Lars P. and K.J. Singleton (1982), "Generalized Instrumental Variables Estimation of Nonlinear Rational Expectations Models", Econometrica 50, n $\mathrm{n}^{\circ}$, pp. $1269-86$.

Hansen, Lars P. and K.J. Singleton (1983), "Stochastic Consumption, Risk Aversion, and the Temporal Behaviour of Asset Returns", Journal of Political Economy 91, n 2, pp. 249-65.

Hansen, Lars P. and K.J. Singleton (1996), "Efficient Estimation of Linear Asset-Pricing Models with Moving Average Errors", Journal of Business and Economic Statistics 14, no 1, pp. 53-68.

Hendry, D. and K. Juselius (2001): "Explaining Cointegration Analysis, part. II", The Energy Journal, 22, no 1, pp. 75-101.

Holden, Darryl and R. Perman (1994), "Unit Roots and Cointegration for the Economist", in Rao, B. Bhaskara (Ed.) (1994), Cointegration for the Applied Economist. (New York: St. Martin's Press).

Johansen, S. (1995), Likelihood-Based Inference in Cointegrated Vector Autoregressive Models. (Oxford: Oxford University Press).

López Salido, J. David (1993), "Consumo y ciclo vital: resultados para España con datos de panel”, Investigaciones Económicas 17, nº 2, pp. 285-312.

Lucas, Robert (1978), “Asset Prices in an Exchange Economy”, Econometrica 46, no 6 , pp. 1429-45.

Lund, Jesper and T. Engsted (1996), "GMM and Present Value Tests of the C-CAPM: Evidence from the Danish, German, Swedish and UK Stock Markets", Journal of International Money and Finance 15, n 4, pp. 497-521.

MacKinnon, James G. (1991), "Critical Values for Cointegration Tests", in R. Engel and C.W.S. Granger (Eds.) (1991), Long-Run Economic Relationships: Readings in Cointegration. (Oxford: Oxford University Press).

Mamaysky, Harry (2001), "Interest Rates and the Durability of Consumption Goods", Yale ICF Working Papers, nº 00-53.

Mehra, Rajnish and E.C. Prescott (1985), "The Equity Premium. A Puzzle”, Journal of Monetary Economics 15, $\mathrm{n}^{\mathrm{o}}$ 2, pp. 145-61.

Meyer, B. (1999), Intertemporal Asset Pricing. Evidence from Germany. (PhysicaVerlag Heidelberg).

Newey, Whitney K. and K.D. West (1987), "A Simple, Positive Semidefinite, Heteroskedasticity and Autocorrelation Consistent Covariance Matrix”, Econometrica 55, no 3, pp. 703-708.

Nielsen, B. and A. Rahbek (2000): "Similarity Issues in Cointegration 
Analysis", Oxford Bulletin of Economics and Statistics 62, $\mathrm{n}^{\circ}$ 1, pp. 5-22.

Ogaki, Masao (1993), "Unit Roots in Macroeconometrics: A Survey", Bank of Japan Monetary and Economic Studies 11, n 2 2, pp. 131-54.

Ogaki, Masao, K. Jang and H. Lim (2003), Structural Macroeconometrics. (The Ohio State University. Manuscript in progress).

Ogaki, Masao and C.M. Reinhart (1998a), "Measuring Intertemporal Substitution: the Role of Durable Goods", Journal of Political Economy 106, n 5, pp. 1078-98.

Ogaki, Masao and C.M. Reinhart (1998b), "Intertemporal Substitution and Durable Goods: Long-Run Data”, Economics Letters 61, pp. 85-90.

Okubo, Masakatsu (2002), "Intertemporal Substitution and Consumer Durables: an Analysis Based on Japanese Data", Institute of Policy and Planned Sciences Working Papers, $\mathrm{n}^{\circ}$ 1016, University of Tsukuba.

Pakos, Michal (2004), “Asset Pricing with Durable Consumption Goods and Non-Homothetic Preferences". Working Paper, Graduate School of Business, University of Chicago.

Park, Joon Y. (1990), "Testing for Unit Roots and Cointegration by Variable Addition", in T.B. Fomby and G.F. Jr. Rhodes (Eds) (1990), Cointegration, Spurious Regressions, and Unit Roots, pp. 107-33. (Advances in Econometrics Series, vol. 8. Greenwich, Conn. and London: JAI Press).

Park, Joon Y. (1992), “Canonical Cointegrating Regressions”, Econometrica 60, no 1, pp. 119-43.

Phillips, Peter C.B. and B.E. Hansen (1990), "Statistical Inference in Instrumental Variables Regression with I(1) Processes", Review of Economic Studies 57, pp. 99-125.

Rodríguez López, R. (1997), “Modelos Intertemporales de Valoración de Activos: Análisis Empírico para el Caso Español”, Revista Española de Economía $14, \mathrm{n}^{\circ} 2$, pp. 189-213.

Rubio, Eva M. (1995), "Testing the CCAPM on Spanish Data: A New Approach", Documentos de Trabajo del Centro de Estudios Monetarios y Financieros, $\mathrm{n}^{\circ}$ 9603.

Stock, J.H. and M.W. Watson (1993), “A Simple Estimator of Cointegrating Vectors in Higher Order Integrated Systems”, Econometrica 61, pp. 783-820.

Uriel, Ezequiel, M.L. Moltó and V. Cucarella (2000), Contabilidad Nacional de España. Series enlazadas 1964-1997 (CNEe-86). (Madrid: Fundación BBV).

Weil, Philippe (1989), “The Equity Premium Puzzle and the Riskfree Rate 
Puzzle", Journal of Monetary Economics 24, n 3, pp. 401-21.

Wirjanto, Tony S. (2004), "Exploring Consumption-Based Asset Pricing Model with Stochastic-Trend Forcing Processes", Applied Economics 36, pp. 1591-97.

Yogo, Motohiro (2005), “A Consumption-Based Explanation of Expected Stock Returns". Journal of Finance (forthcoming). 
${ }^{1}$ Using the terminology typical of asset pricing literature, we could say that, to a certain extent and according to the specification of the preferences employed, the results reflect both the risk premium puzzle, Mehra and Prescott (1985), and the interest rate puzzle, Weil (1989). A detailed analysis of the empirical puzzles of the CCAPM model, and of some of the solutions proposed, can be found, among others, in Campbell (2003).

${ }^{2}$ We are referring to the consideration of phenomena such as durability or the formation of consumption habits, as in the case, among others, of Dunn and Singleton (1986) or Campbell and Cochrane (2000) or to the rupture with the expected utility approach in the work of Epstein and Zin (1991).

${ }^{3}$ Focusing on the Spanish case, López Salido (1993) analyses the intratemporal separability of preferences using microeconomic data from the Encuesta Continua de Presupuestos Familiares for the 1985-89 period.

${ }^{4}$ Note that if $\varepsilon=1$, expression [2] converges to the Cobb-Douglas function, whereas if $\varepsilon=0$, the current utility would converge to Leontief's utility function. For a detailed analysis, see Pakos (2004).

5 We can therefore test the assumption of intratemporal separability by testing the null hypothesis $\varepsilon=\sigma$.

${ }^{6}$ Specifically, Ogaki and Reinhart consider an endowment economy in which their logarithm is stationary. On the other hand, Ogaki and Reinhart (1998a) and Okubo (2002) show that, although the stationarity of $\frac{U M a_{1, t+\tau}}{U M a_{1, t}}$ is not necessarily derived from the model's assumptions, it is a valid assumption, at least from an empirical perspective.

${ }^{7}$ For a detailed study of this technique, see, among others, Ogaki (1993) and Ogaki, Jang and $\operatorname{Lim}(2003)$.

8 The difference between the two concepts is based on the fact that the cointegration vector which eliminates the stochastic trends among the variables can also eliminate determinist trends or not. In the first case, we refer to determinist cointegration, whereas if the determinist trends are not eliminated by the cointegration vector, this is a case of stochastic cointegration. For details of the determinist and stochastic cointegration concepts, see, among others, Ogaki (1993).

${ }_{9}$ Other methods also lead to estimators with all the desirable properties. This is the case for the methods of Phillips and Hansen (1990) and Stock and Watson (1993).

10 This method (the properties of which make it particularly useful in a multivariate context) also allows for stationarity tests on the series involved in the analysis, so it is possible to complete the study of their order of integration provided by unit root tests.

11 See Hendry and Juselius (2001).

12 In this respect, we have followed Esteve and Tamarit (1994).

${ }_{13} R_{t+1}^{f, j}$ is the real interest rate of country $j, j=$ Germany, Spain, France, and $R_{t+1}^{i}$ is the real gross rate of return of financial asset $i, i=D A X 30, I G T B M, C A C 40$ (abbreviations of the stock indices used to calculate the nominal rates of return for Germany, Spain and France). 14 To determine the cointegration rank, the information provided by the trace test in table 2 has been completed, in all cases, with an analysis of the roots of the characteristic polynomial and with the $t$ statistics of the adjustment coefficients $\alpha$. The critical values of the $95 \%$ trace test were obtained from Johansen (1995).

15 According to the stationarity tests applied, $\left(c_{t}-d_{t}\right)$ cannot be rejected as stationary, in line with the results of the ADF and PP unit root tests, when we consider a constant in the datagenerating process. In all the estimated long-term ratios, we have performed the relevant exclusion, stationarity and weak parameter exogeneity tests by means of LR tests distributed like a $\chi^{2}(2)$ the degrees of freedom of which depend on the constraints established. We have also tested the VAR residues to verify that they present neither autocorrelation nor heterocedasticity and that they verify the hypothesis of normality (although, if this hypothesis is not confirmed, Gonzalo [1994] showed that the results of the estimation would continue to be robust). According to the information criteria of Akaike and Schwarz, the number of lags used in the VAR is 1 in the estimations for Spain and Germany and 2 for France.

${ }_{16}$ The results of the ADF and Phillips-Perron unit root tests for variables $c_{t}$ y $d_{t}$ show that we cannot reject them as non-stationary. The results are available upon request to the authors. 
17 The unit root tests do not reject the stationarity of variables $c_{t}$ and $d_{t}$ for some of their specifications. The results of these tests are available upon request from the authors and they are confirmed to a certain extent by the results obtained for this specification of preferences with the Johansen method.

18 Since with $r=2$ the module with the greater characteristic root is not too close to 1 and, moreover, both price and durable consumption react significantly to deviations in the longterm ratio.

${ }^{19}$ Moreover, in this case, it cannot be rejected that $c_{t}$ and $d_{t}$ are stationary variables.

20 With this level of significance, the stationary test applied enables us to reject that relative consumption is stationary.

${ }^{21}$ For an explanation, see Ogaki (1993) and Ogaki et. al. (2003).

22 See section 3.

${ }^{23}$ In the case of France, since the real interest rate is not stationary, the variable on levels has been replaced by its gross growth rate.

24 We are referring to the Hansen and Singleton model (1982, 1983).

25 The results are somewhat less puzzling when we consider utility function specifications which are not intertemporally separable.

${ }^{26}$ For example, Ogaki and Reinhart apply a value of $\beta$ equal to 0.99 and 0.995 for quarterly data; in other words, the annual subjective discount factor takes on values of 0.9605 and 0.9801.

27 We are unaware of microeconometric estimations of this parameter for the other two countries considered.

${ }_{28}$ We are referring to the Order of the Ministry of Economy and Public Finance of December 15,1998 , annex IV. In these tables, we have taken the number of years after which the vehicle in question is less than 15 per cent of its initial value. The parameters have been estimated considering larger and smaller periods of time, without the results varying significantly. All the results are available upon request from the authors.

Since we are unaware of the existence of similar tables for Germany and France, we have applied the procedure used for Spain to these two countries.

${ }^{29}$ Depreciation rates have been taken from the aforementioned tables. 
Table 1: UNIT ROOT TESTS

\begin{tabular}{|c|c|c|c|c|c|c|c|c|c|}
\hline \multirow{2}{*}{$\begin{array}{c}\text { ADF } \\
\text { TEST }\end{array}$} & \multicolumn{3}{|c|}{ GERMANY } & \multicolumn{3}{|c|}{ SPAIN } & \multicolumn{3}{|c|}{ FRANCE } \\
\hline & (1) & (2) & (3) & (1) & (2) & (3) & (1) & (2) & (3) \\
\hline$p_{t}$ & $\begin{array}{c}-1.56 \\
(0)\end{array}$ & $\begin{array}{c}-1.21 \\
(0)\end{array}$ & $\begin{array}{c}1.72 \\
(0)\end{array}$ & $\begin{array}{c}-0.98 \\
(0)\end{array}$ & $\begin{array}{c}-0.26 \\
(0)\end{array}$ & $\begin{array}{c}0.20 \\
(0)\end{array}$ & $\begin{array}{c}-2.32 \\
(1)\end{array}$ & $\begin{array}{c}-0.21 \\
(1)\end{array}$ & $\begin{array}{c}-1.97 * * \\
(1)\end{array}$ \\
\hline$\Delta p_{t}$ & $\begin{array}{c}-4.49 * * * \\
(0)\end{array}$ & $\begin{array}{c}-4.55^{* * *} \\
(0)\end{array}$ & $\begin{array}{c}-3.97^{* * *} \\
(0)\end{array}$ & $\begin{array}{c}-6.10^{* * *} \\
(0)\end{array}$ & $\begin{array}{c}-5.89 * * * \\
(0)\end{array}$ & $\begin{array}{c}-5.77 * * * \\
(0)\end{array}$ & $\begin{array}{c}-3.96^{* *} \\
(0)\end{array}$ & $\begin{array}{c}-4.00^{* * *} \\
(0)\end{array}$ & $\begin{array}{c}-2.71^{* * * *} \\
(0)\end{array}$ \\
\hline$c_{t}-d_{t}$ & $\begin{array}{c}-2.59 \\
(1)\end{array}$ & $\begin{array}{c}-2.65^{*} \\
(1)\end{array}$ & $\begin{array}{c}-0.33 \\
(0)\end{array}$ & $\begin{array}{c}-3.32 * \\
(1)\end{array}$ & $\begin{array}{c}-2.63^{*} \\
(1)\end{array}$ & $\begin{array}{c}-1.38 \\
(1)\end{array}$ & $\begin{array}{c}-2.37 \\
(0)\end{array}$ & $\begin{array}{c}-2.78^{*} \\
(0)\end{array}$ & $\begin{array}{c}-2.67 \text { *** } \\
(0)\end{array}$ \\
\hline$\Delta\left(c_{t}-d_{t}\right)$ & $\begin{array}{c}-4.30^{* * * *} \\
(0)\end{array}$ & $\begin{array}{c}-4.35^{* * *} \\
(0)\end{array}$ & $\begin{array}{c}-4.43^{* * *} \\
(0)\end{array}$ & $\begin{array}{c}-3.83^{* *} \\
(0)\end{array}$ & $\begin{array}{c}-3.71 * * * \\
(0)\end{array}$ & $\begin{array}{c}-3.59^{* * *} \\
(0)\end{array}$ & $\begin{array}{c}-5.55^{* * *} \\
(0)\end{array}$ & $\begin{array}{c}-5.36 * * * \\
(0)\end{array}$ & $\begin{array}{c}-4.88^{\text {*** }} \\
(0)\end{array}$ \\
\hline$R_{t+1}^{f}$ & $\begin{array}{c}-3.56^{* *} \\
(1)\end{array}$ & $\begin{array}{c}-3.63^{* *} \\
(0)\end{array}$ & $\begin{array}{c}-0.20 \\
(0)\end{array}$ & $\begin{array}{c}-4.48^{* * *} \\
(0)\end{array}$ & $\begin{array}{c}-4.24^{* * * *} \\
(0)\end{array}$ & $\begin{array}{c}-0.10 \\
(0)\end{array}$ & $\begin{array}{c}-2.62 \\
(0)\end{array}$ & $\begin{array}{c}-1.97 \\
(0)\end{array}$ & $\begin{array}{c}0.14 \\
(0)\end{array}$ \\
\hline$R_{t+1}^{j}$ & $\begin{array}{c}-3.48^{*} \\
(0) \\
\end{array}$ & $\begin{array}{c}-3.60^{* *} \\
(0) \\
\end{array}$ & $\begin{array}{c}-0.41 \\
(2) \\
\end{array}$ & $\begin{array}{c}-3.24 * * \\
(0) \\
\end{array}$ & $\begin{array}{c}-3.26^{* *} \\
(0) \\
\end{array}$ & $\begin{array}{c}-0.66 \\
(0) \\
\end{array}$ & $\begin{array}{c}-5.40^{* * *} \\
(0) \\
\end{array}$ & $\begin{array}{c}-4.68^{* * *} \\
(0)\end{array}$ & $\begin{array}{c}-0.12 \\
(2) \\
\end{array}$ \\
\hline
\end{tabular}

PP

TEST (1) (2)

SPAIN

\section{FRANCE}

(3) (1) (2)

$\begin{array}{llll}\text { (3) } & \text { (1) } & \text { (2) } & \text { (3) }\end{array}$

\begin{tabular}{|c|c|c|c|c|c|c|c|c|c|}
\hline$p_{t}$ & $\begin{array}{c}-1.84 \\
(3)\end{array}$ & $\begin{array}{c}-1.29 \\
(3)\end{array}$ & $\begin{array}{c}1.17 \\
(3)\end{array}$ & $\begin{array}{c}-1.09 \\
(3)\end{array}$ & $\begin{array}{c}-0.41 \\
(3)\end{array}$ & $\begin{array}{c}0.01 \\
(3)\end{array}$ & $\begin{array}{c}-1.77 \\
(3)\end{array}$ & $\begin{array}{c}-0.07 \\
(3)\end{array}$ & $\begin{array}{c}-2.73^{* * *} \\
(3)\end{array}$ \\
\hline$\Delta p_{t}$ & $\begin{array}{c}-4.58^{* * *} \\
(3)\end{array}$ & $\begin{array}{c}-4.63^{* * *} \\
\text { (3) }\end{array}$ & $\begin{array}{c}-4.04^{* * *} \\
\text { (3) }\end{array}$ & $\begin{array}{c}-6.10^{* * *} \\
\text { (3) }\end{array}$ & $\begin{array}{c}-5.89 * * * \\
\text { (3) }\end{array}$ & $\begin{array}{c}-5.79 * * * \\
\text { (3) }\end{array}$ & $\begin{array}{c}-3.90^{* *} \\
(3)\end{array}$ & $\begin{array}{c}-3.94 * * * \\
\text { (3) }\end{array}$ & $\begin{array}{c}-2.54^{* * *} \\
\text { (3) }\end{array}$ \\
\hline$c_{t}-d_{t}$ & $\begin{array}{c}-2.36 \\
(3)\end{array}$ & $\begin{array}{c}-2.67^{*} \\
3)\end{array}$ & $\begin{array}{c}-0.92 \\
(3)\end{array}$ & $\begin{array}{c}-2.94 \\
(3)\end{array}$ & $\begin{array}{c}-2.87^{*} \\
(3)\end{array}$ & $\begin{array}{c}0.73 \\
\text { (3) }\end{array}$ & $\begin{array}{c}-2.37 \\
(3)\end{array}$ & $\begin{array}{c}-2.85^{*} \\
(3)\end{array}$ & $\begin{array}{c}-2.54 * * \\
(3)\end{array}$ \\
\hline$\Delta\left(c_{t}-d_{t}\right)$ & $\begin{array}{c}-4.25^{* *} \\
\text { (3) }\end{array}$ & $\begin{array}{c}-4.30^{* * *} \\
\text { (3) }\end{array}$ & $\begin{array}{c}-4.39^{* * *} \\
\text { (3) }\end{array}$ & $\begin{array}{c}-3.78^{* *} \\
\text { (3) }\end{array}$ & $\begin{array}{c}-3.62^{* *} \\
\text { (3) }\end{array}$ & $\begin{array}{c}-3.42^{* * *} \\
\text { (3) }\end{array}$ & $\begin{array}{c}-5.50^{* * *} \\
\text { (3) }\end{array}$ & $\begin{array}{c}-5.31 * * * \\
\text { (3) }\end{array}$ & $\begin{array}{c}-4.84^{* * *} \\
\text { (3) }\end{array}$ \\
\hline$R_{t+1}^{f}$ & $\begin{array}{c}-3.62^{* *} \\
\text { (3) }\end{array}$ & $\begin{array}{c}-3.59^{* *} \\
\text { (3) }\end{array}$ & $\begin{array}{c}-0.27 \\
(3)\end{array}$ & $\begin{array}{c}-5.44 * * * \\
\text { (3) }\end{array}$ & $\begin{array}{c}-4.97 * * * \\
\text { (3) }\end{array}$ & $\begin{array}{c}0.00 \\
(3)\end{array}$ & $\begin{array}{c}-2.65 \\
(3)\end{array}$ & $\begin{array}{c}-1.89 \\
(3)\end{array}$ & $\begin{array}{c}0.20 \\
(3)\end{array}$ \\
\hline$R_{t+1}^{j}$ & $\begin{array}{c}-3.47^{*} \\
(3) \\
\end{array}$ & $\begin{array}{c}-3.58^{* *} \\
\text { (3) }\end{array}$ & $\begin{array}{c}-0.54 \\
(3) \\
\end{array}$ & $\begin{array}{c}-3.75^{*} \\
(3)\end{array}$ & $\begin{array}{c}-3.78^{* *} \\
(3)\end{array}$ & $\begin{array}{c}-0.65 \\
(3)\end{array}$ & $\begin{array}{c}-5.35^{* * *} * \\
(3)\end{array}$ & $\begin{array}{c}-4.74^{* * *} \\
\text { (3) }\end{array}$ & $\begin{array}{c}-0.78 \\
(3)\end{array}$ \\
\hline
\end{tabular}

Notes: 1. In the table, $(* * *)$ indicates rejection of the null hypothesis of existence of unit roots at a 1 per cent, (**) 5 per cent and $\left(^{*}\right) 10$ per cent of significance level. The critical values were obtained from MacKinnon (1991). The number of lags chosen (in brackets) for the ADF test is the number for which the greatest lag of the variable in first differences is significant, starting with a lag of $\mathrm{k}=4$, and for the Phillips-Perron test the number corresponding to the Newey and West procedure (1987).

2. Beneath columns (1), (2) and (3) are the results of the tests for the models with constant and trend, with constant, and without constant or trend, respectively. 
Table 2: COINTEGRATION TESTS

\begin{tabular}{|c|c|c|c|c|c|c|c|c|}
\hline & \multicolumn{5}{|c|}{ PARK H(p,q) } & \multicolumn{3}{|c|}{ TRACE TEST } \\
\hline & $\bar{H}(1,0)$ & $H(1,2)$ & $H(1,3)$ & $\begin{array}{l}H(1,4) \\
\end{array}$ & $H(1,5)$ & Trace & est & VC $(95 \%)$ \\
\hline \multicolumn{9}{|l|}{ GERMANY } \\
\hline $\begin{array}{l}\text { HOMOTHETIC } \\
\text { PREF. }\end{array}$ & $\begin{array}{c}0.5252 \\
{[0.4686]} \\
\end{array}$ & $\begin{array}{c}3.4293 \\
{[0.0641]} \\
\end{array}$ & $\begin{array}{c}3.5476 \\
{[0.1697]} \\
\end{array}$ & $\begin{array}{c}3.7700 \\
{[0.2874]} \\
\end{array}$ & $\begin{array}{c}4.5391 \\
{[0.3379]} \\
\end{array}$ & $\begin{array}{l}r=0 \\
r=1\end{array}$ & $\begin{array}{l}23.66 \\
9.09 \\
\end{array}$ & $\begin{array}{c}19.99 \\
9.13 \\
\end{array}$ \\
\hline $\begin{array}{c}\text { NON-HOMOTHETIC } \\
\text { PREF. }\end{array}$ & $\begin{array}{l}12.6513 \\
{[0.0004]}\end{array}$ & $\begin{array}{r}0.0172 \\
{[0.8955}\end{array}$ & $\begin{array}{c}0.2214 \\
{[0.8952]}\end{array}$ & $\begin{array}{c}0.3691 \\
{[0.9466]}\end{array}$ & $\begin{array}{c}0.4095 \\
{[0.9817]}\end{array}$ & $\begin{array}{l}\text { Model (1) } \\
r=0 \\
r=1 \\
r=2 \\
\text { Model (2) } \\
r=0 \\
r=1 \\
r=2\end{array}$ & $\begin{array}{c}64.59 \\
14.56 \\
3.02 \\
42.55 \\
23.59 \\
10.32\end{array}$ & $\begin{array}{c}34.79 \\
19.99 \\
9.13 \\
42.20 \\
25.47 \\
12.39\end{array}$ \\
\hline \multicolumn{9}{|l|}{ SPAIN } \\
\hline $\begin{array}{l}\text { HOMOTHETIC } \\
\text { PREF. }\end{array}$ & $\begin{array}{l}4.5778 \\
{[0.0324]}\end{array}$ & $\begin{array}{c}3.5228 \\
{[0.0605]}\end{array}$ & $\begin{array}{l}4.4419 \\
{[0.1085]}\end{array}$ & $\begin{array}{c}5.1715 \\
{[0.1597]}\end{array}$ & $\begin{array}{c}5.5292 \\
{[0.2372]}\end{array}$ & $\begin{array}{l}r=0 \\
r=1\end{array}$ & $\begin{array}{c}23.08 \\
1.09\end{array}$ & $\begin{array}{c}19.99 \\
9.13\end{array}$ \\
\hline $\begin{array}{c}\text { NON-HOMOTHETIC } \\
\text { PREF. }\end{array}$ & $\begin{array}{c}0.0456 \\
{[0.8309]}\end{array}$ & $\begin{array}{l}18.3824 \\
{[0.0000]}\end{array}$ & $\begin{array}{l}24.1480 \\
{[0.0000]}\end{array}$ & $\begin{array}{l}24.4114 \\
{[0.0000]}\end{array}$ & $\begin{array}{l}29.7579 \\
{[0.0000]}\end{array}$ & $\begin{array}{l}\text { Model (1) } \\
r=0 \\
r=1 \\
r=2 \\
\text { Model (2) } \\
r=0 \\
r=1 \\
r=2\end{array}$ & $\begin{array}{c}107.3 \\
17.93 \\
3.96 \\
74.14 \\
23.04 \\
6.85\end{array}$ & $\begin{array}{c}34.79 \\
19.99 \\
9.13 \\
42.20 \\
25.47 \\
12.39\end{array}$ \\
\hline \multicolumn{9}{|l|}{ FRANCE } \\
\hline $\begin{array}{l}\text { HOMOTHETIC } \\
\text { PREF. }\end{array}$ & $\begin{array}{c}0.5617 \\
{[0.4536]}\end{array}$ & $\begin{array}{c}2.1722 \\
{[0.1405]}\end{array}$ & $\begin{array}{c}2.2262 \\
{[0.3285]}\end{array}$ & $\begin{array}{c}2.7404 \\
{[0.4334]}\end{array}$ & $\begin{array}{c}3.0988 \\
{[0.5414]}\end{array}$ & $\begin{array}{l}r=0 \\
r=1\end{array}$ & $\begin{array}{l}18.13 \\
2.77\end{array}$ & $\begin{array}{c}19.99 \\
9.13\end{array}$ \\
\hline $\begin{array}{c}\text { NON-HOMOTHETIC } \\
\text { PREF. }\end{array}$ & $\begin{array}{c}0.0459 \\
{[0.8303]}\end{array}$ & $\begin{array}{c}0.3818 \\
{[0.5367]}\end{array}$ & $\begin{array}{l}16.9492 \\
{[0.0002]}\end{array}$ & $\begin{array}{l}19.1085 \\
{[0.0003]}\end{array}$ & $\begin{array}{l}22.4148 \\
{[0.0002]}\end{array}$ & $\begin{array}{l}\text { Model (1) } \\
r=0 \\
r=1 \\
r=2 \\
\text { Model (2) } \\
r=0 \\
r=1 \\
r=2\end{array}$ & $\begin{array}{c}43.19 \\
17.73 \\
5.45 \\
\\
45.51 \\
21.09 \\
8.26\end{array}$ & $\begin{array}{c}34.79 \\
19.99 \\
9.13 \\
\\
42.20 \\
25.47 \\
12.39\end{array}$ \\
\hline
\end{tabular}

Notes: the values in square brackets are asymptotic $\mathrm{p}$ values 
Table 3: INTRATEMPORAL ELASTICITY OF SUBSTITUTION

\begin{tabular}{|c|c|c|c|c|}
\hline COUNTRY & PARAMETER & PARK CCR & \multicolumn{2}{|c|}{ JOHANSEN } \\
\hline \multicolumn{5}{|l|}{ GERMANY } \\
\hline \multirow{3}{*}{$\begin{array}{l}\text { HOMOTHETIC } \\
\text { PREF. }\end{array}$} & $\bar{\mu}$ & $1.43^{* * *}$ & \multicolumn{2}{|c|}{$1.46^{*}$} \\
\hline & $\varepsilon$ & 0.26 & \multicolumn{2}{|c|}{1.12} \\
\hline & & & Model (1) & Model (2) \\
\hline \multirow{3}{*}{$\begin{array}{l}\text { NON- } \\
\text { HOMOTHETIC } \\
\text { PREF. }\end{array}$} & $b$ & $1.48^{* * *}$ & 1.29 & n.a. \\
\hline & $\varepsilon$ & $0.77 * * *$ & $1.22 *$ & $0.91 *$ \\
\hline & $\eta$ & $0.98^{* * *}$ & $1.04^{* * *}$ & $1.03 * *$ \\
\hline \multicolumn{5}{|l|}{ SPAIN } \\
\hline \multirow{3}{*}{$\begin{array}{l}\text { HOMOTHETIC } \\
\text { PREF. }\end{array}$} & $\mu$ & $1.38^{* * *}$ & \multicolumn{2}{|c|}{$1.31^{* * *}$} \\
\hline & $\varepsilon$ & $1.44 * * *$ & \multicolumn{2}{|c|}{$0.94 * * *$} \\
\hline & & & Model (1) & Model (2) \\
\hline \multirow{3}{*}{$\begin{array}{c}\text { NON- } \\
\text { HOMOTHETIC } \\
\text { PREF. }\end{array}$} & $b$ & $5.02^{* * *}$ & $6.41^{* * *}$ & (a) $0.01 * * *$ \\
\hline & $\varepsilon$ & -0.08 & $-0.74 * * *$ & -0.18 \\
\hline & $\eta$ & $0.64^{* * *}$ & $0.51 * *$ & $0.44 * * *$ \\
\hline \multicolumn{5}{|l|}{ FRANCE } \\
\hline \multirow{3}{*}{$\begin{array}{l}\text { HOMOTHETIC } \\
\text { PREF. }\end{array}$} & 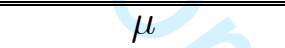 & $1.71 * * *$ & \multicolumn{2}{|c|}{$1.64 * * *$} \\
\hline & $\varepsilon$ & $0.95^{* * *}$ & \multicolumn{2}{|c|}{$0.63^{*}$} \\
\hline & & & Model (1) & Model (2) \\
\hline NON- & $b$ & $5.76^{* * *}$ & $14.10^{* * *}$ & n.a. \\
\hline HOMOTHETIC & $\varepsilon$ & $-0.36 * * *$ & $-1.41 * *$ & $-1.25 * *$ \\
\hline PREF. & $\eta$ & $0.65^{* * *}$ & $-0.05^{* *}$ & 0.09 \\
\hline
\end{tabular}

Notes: In the table, $\left({ }^{* *}\right)$ indicates that the estimated parameter is significantly different from zero at a 1 per cent, $\left({ }^{* *}\right)$ 5 per cent and $(*) 10$ per cent level of significance.

(a) In the case of Model (2) for Spain, it shows the estimated value of the trend 
Table 4: INTERTEMPORAL ELASTICITY OF SUBSTITUTION

\begin{tabular}{|c|c|c|c|c|c|c|}
\hline Country & \multicolumn{2}{|c|}{$\begin{array}{c}\text { Stage } 1 \\
\text { estimations }\end{array}$} & INSTRUMENTS & $\beta$ & $\sigma$ & J-Test \\
\hline \multicolumn{7}{|l|}{ GERMANY } \\
\hline & \multirow{2}{*}{$\begin{array}{c}\varepsilon \\
0.7707\end{array}$} & \multirow{2}{*}{$\begin{array}{c}\eta \\
0.9881\end{array}$} & $\overline{I 1}$ & $\begin{array}{c}0.9355 \\
{[0.0000]}\end{array}$ & $\begin{array}{c}1.6353 \\
{[0.0000]}\end{array}$ & $\begin{array}{c}5.2793 \\
{[0.2598]}\end{array}$ \\
\hline & & & $I 2$ & $\begin{array}{c}0.9706 \\
{[0.0000]}\end{array}$ & $\begin{array}{c}1.2979 \\
{[0.0000]}\end{array}$ & $\begin{array}{c}5.8883 \\
{[0.2320]}\end{array}$ \\
\hline \multicolumn{7}{|l|}{ SPAIN } \\
\hline & \multirow{2}{*}{\multicolumn{2}{|c|}{1.4368}} & $\overline{I 11}$ & $\begin{array}{c}0.9478 \\
{[0.0000]}\end{array}$ & $\begin{array}{c}3.2735 \\
{[0.0000]}\end{array}$ & $\begin{array}{c}3.8161 \\
{[0.4314]}\end{array}$ \\
\hline & & & $I 2$ & $\begin{array}{c}0.9187 \\
{[0.0000]}\end{array}$ & $\begin{array}{c}2.3714 \\
{[0.0000]}\end{array}$ & $\begin{array}{c}3.8221 \\
{[0.4307]}\end{array}$ \\
\hline \multicolumn{7}{|l|}{ FRANCE } \\
\hline & \multirow{2}{*}{\multicolumn{2}{|c|}{0.953}} & $I 1$ & $\begin{array}{c}0.8716 \\
{[0.0000]}\end{array}$ & $\begin{array}{c}2.3018 \\
{[0.0000]}\end{array}$ & $\begin{array}{c}0.2712 \\
{[0.6025]}\end{array}$ \\
\hline & & & $I 2$ & $\begin{array}{c}0.8826 \\
{[0.0000]}\end{array}$ & $\begin{array}{c}2.2196 \\
{[0.0000]}\end{array}$ & $\begin{array}{c}1.7750 \\
{[0.1827]}\end{array}$ \\
\hline
\end{tabular}

Notes: the values in square brackets are asymptotic $\mathrm{p}$ values 
Table 5: SEPARABLE MODEL

\begin{tabular}{|c|c|c|c|}
\hline \hline Country & $\beta$ & $\sigma$ & J-Test \\
\hline \hline GERMANY & \multicolumn{3}{|c|}{} \\
\hline \hline & 0.9355 & $\begin{array}{c}0.0010 \\
{[0.0000]}\end{array}$ & $\begin{array}{c}8.3934 \\
{[0.1358]}\end{array}$ \\
\hline \hline SPAIN & & \\
\hline & 0.9478 & 0.0081 & 9.1375 \\
& & {$[0.0032]$} & {$[0.0103]$} \\
\hline \hline FRANCE & 0.8716 & -0.2155 & 1.4122 \\
& & {$[0.0000]$} & {$[0.4935]$} \\
\hline \hline
\end{tabular}

Notes: the values in square brackets are asymptotic p values 
